\begin{tabular}{|c|c|c|c|c|c|}
\hline 加藤久美子 ${ }^{1)}$ & 遠山ゆり子1) & 大戸 & 斉1) & 元木 & 良一1) \\
\hline 遠藤 力 ${ }^{2)}$ & 佐藤 章 ${ }^{2)}$ & 高崎 & 克哲 ${ }^{3)}$ & 星 & 岩雄 ${ }^{3)}$ \\
\hline 今村＼cjkstart真哉4) & 菅藤 & 森田 & 庄治6) & 半戸 & 啓一6) \\
\hline 服部 理男6) & & & & & \\
\hline
\end{tabular}

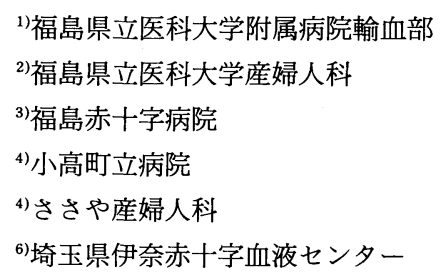

(平成 7 年 10 月 2 日受付)

(平成 8 年 2 月 26 日受理)

\title{
PRENATAL HPA-4 GENOTYPING AT RISK FOR NEONATAL ALLOIMMUNE THROMBOCYTOPENIA USING AMNIOTIC FLUID CELLS
}

\author{
Kumiko Kato ${ }^{1}$, Yuriko Tohyama ${ }^{1)}$, Hitoshi Ohto ${ }^{1)}$, Ryoichi Motoki ${ }^{1)}$, \\ Chikara Endo ${ }^{2)}$, Akira Sato ${ }^{2)}$, Katsunori Takasaki ${ }^{3)}$, \\ Shinya Imamura ${ }^{4)}$, Mitsuru Sugafuji ${ }^{5)}$, Shoji Morita ${ }^{6)}$, \\ Keiichi Hando ${ }^{1)}$ and Masao Hattori ${ }^{6)}$ \\ ${ }^{1)}$ Blood Transfusion Service \\ ${ }^{2}$ Department of Obstetrics and Gynecology, Fukushima Medical College \\ ${ }^{3)}$ Japanese Red Cross Fukushima Hospital \\ ${ }^{4)}$ Odaka Town Hospital \\ ${ }^{5)}$ Sasaya Sanfujinka \\ ${ }^{6)}$ Japanese Red Cross Saitama-Ina Blood Center
}

Optimal management of neonatal alloimmune thrombocytopenia (NAIT) requires the determination of fetal platelet antigen status as early as possible. We explored the feasibility of fetal HPA-4 genotyping by amplification of DNA from amniotic fluid cells using PCR-SSP. Three fetuses in which fetal HPA-4 type from amniotic fluid cells was completely concordant with typing using the blood of these infants were studied. Two babies were shown to be homozygous HPA-4a/a, and had normal platelet counts. The third fetus was heterozygous HPA-4a/b incompatible with maternal antibody, and developed mild thrombocytopenia $(116,000 / \mu 1)$. These findings suggest that HPA genotype can be reliably and rapidly determined from amniotic fluid by DNA amplification.

Key words: neonatal alloimmune thrombocytopenia, HPA-4, prenatal diagnosis, DNA genotyping, platelet

\section{はじめに}

赤血球型 Rho (D) や, $\mathrm{ABO}$ 型不適合で新生児 溶血性疾患がおこるのと同様な機序で，血小板特
異抗原型 human platelet antigen（HPA）の母児 間不適合が新生児血小板減少症 neonatal alloimmune thrombocytopenia（NAIT）の原因となる 
ことが知られている. 重篤な場合, 胎児脳内出血, 水頭症を合併することもある ${ }^{1)}$. NAIT が発症し, 血小板輸血等が必要となった場合，迅速に対応す るためには出生前診断が不可欠となる。しかし， 母親の抗 HPA 抗体価の変動や臍帯血の血小板数 から推測する血清学的診断には限界があり, DNA タイピングが有用であると考える。そこで比較的 簡単に採取できる羊水を用い，血小板型 DNA 夕 イピングをする事により, 出生前に NAIT 発症の 可能性を確認できないか検討を行った．高力価の 抗 HPA-4b 抗体を保有する妊婦 3 例に羊水穿刺 を行い, うち 2 例では NAIT 発症を否定し, 1 例 にNAIT 発症の可能性を予測しえたので報告す る.

\section{方 法}

血小板抗体スクリーニング・抗体特異性同定, HPA 抗原同定，および抗体価測定には，混合受身 凝集法 (MPHA 法) ${ }^{2)}$ を用いた。血小板パネルは, 血小板型既知の $\mathrm{O}$ 型健常人の血小板を使用した。 血小板遺伝子型タイピングは, PCR-SSP 法3)を 用いた，末梢血，臍帯血は，単核球層を分離し， DNA 抽出試薬 (セパジーン：三光純薬）を用いて DNA を抽出した。羊水は $2,500 \mathrm{rpm} 10$ 分間遠心 後，沈澱した羊水細胞から同様の方法で DNA を 抽出した. 抽出した DNA は滅菌水で $50 \mathrm{ng} / \mathrm{m} l$ に 調整し，プライマー（Table 1) を加え， Taq polymerase $5 \mathrm{U}$ の存在下で, $95^{\circ} \mathrm{C}(1 \mathrm{~min}), 68^{\circ} \mathrm{C}$ (1min), $72^{\circ} \mathrm{C}$ (1min) を30cycle 繰り返し増幅し

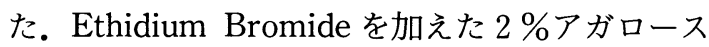
ゲルに増幅産物を添加し, 電気泳動した後, 紫外 線照射下で観察した。

\section{結果}

\section{症例 1}

母親：32歳, B 型, RhoD $(+)$, 輸血歴なし. 5 妊 2 産. 妊娠初期（妊娠 4 週, 妊娠 12 週）に自 然流産を 2 回，人工流産を 1 回経験している。自 然流産の原因として抗 HPA 抗体の関与は不明で ある. 6 度目の妊娠第 8 週時に抗 HPA- $4 \mathrm{~b}$ 抗体陽 性, 抗体価は640倍以上と判明した。妊娠 12 週時の 抗体価は, 1,280倍, 夫の血小板に対する抗体価は 2,560 倍と高力価であった。妊娠37週に正常分婏に て女児を出生した。

児：A 型, RhoD $(+)$

臍帯血血小板数は, $28.4 \times 10^{4} / \mu l$, 生後 3 日の血 小板は, $19.6 \times 10^{4} / \mu l$ であった，出血傾向もみら れず，その他の異常所見も認めなかった。

血小板型は，MPHA 法を用いた表現型，PCRSSP 法を用いた遺伝子型ともに，父親は HPA-4 $\mathrm{a} / \mathrm{b}$, 母親は HPA-4a/a であった.妊娠 17 週に羊水 穿刺を実施し，この羊水細胞を用い血小板遺伝子 型タイピングを行った。胎児は，母親と同型の HPA-4a/aであった為，児の血小板は母親の抗 HPA-4b 抗体に感作, 破壊される事はなく, NAIT は発症しないと出生前に推測した。出生後, 分婏 時の臍帯血，児の未梢血についてタイピングを行 い，羊水細胞の血小板型と一致することを確認し た (Fig. 1).

\section{症例 2}

母親：32歳, B 型, RhoD (+), 輸血歴なし。 2 妊 2 産. 妊娠14週に抗 HPA-4b 抗体陽性と判明 し, 妊娠24週時の抗体価は32倍, 37週時の抗体価 は64倍であった４0週に正常分婏にて女児を出産 した.

児：O 型, RhoD (+)

Table 1 Sequence of primers for PCR-SSP (Ref. 4)

\begin{tabular}{c|c|c}
\hline & specificity & \multicolumn{1}{c}{ sequence } \\
\hline HPA-4 & $4 \mathrm{a}$ & $5^{\prime}$-GCT GGC CAC CCA GAT GCG-3' \\
& $4 \mathrm{~b}$ & $5^{\prime}$-GCT GGC CAC CCA GAT GCA-3' \\
& common & $5^{\prime}$-TAG CAG GGG TTT TCG AGG GCC TCT-3' \\
\hline
\end{tabular}

For HPA-4, either $4 \mathrm{a}$ or $4 \mathrm{~b}$ primer was included in the PCR reaction mixture with antisense primer 


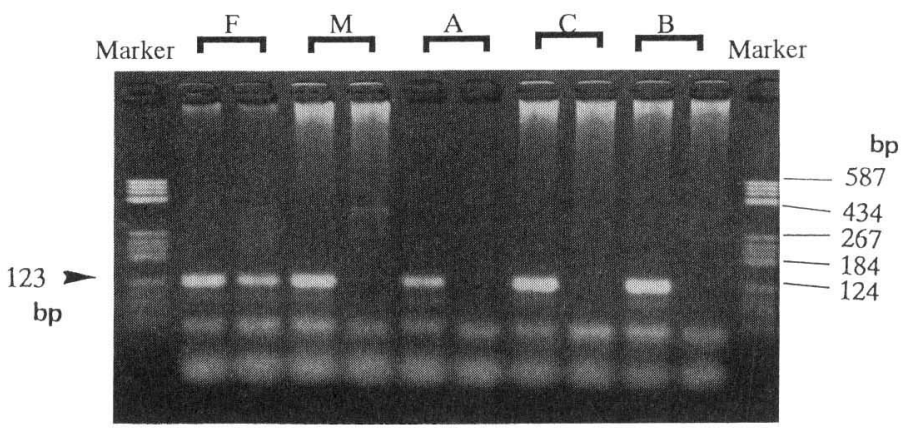

Fig. 1 Result of genotyping for HPA-4 by PCR-SSP. Specific PCR products were of the expected size of 123bp (HPA-4a and HPA-4b). Some unexpected small bands, which seemed to be nonspecific PCR products, were observed in the result of HPA-4.

Fig. 1a Case 1

F : PCR products of the father's blood; HPA- $4 \mathrm{a} / \mathrm{b}$ heterozygous, $\mathrm{M}$ : Mother; HPA-4a/a homozygous, A : PCR products from amniotic fluid cells; HPA-4a/a homozygous, C: (cord blood), and B (infant's peripheral blood) were shown to be homozygous HPA-4a/a

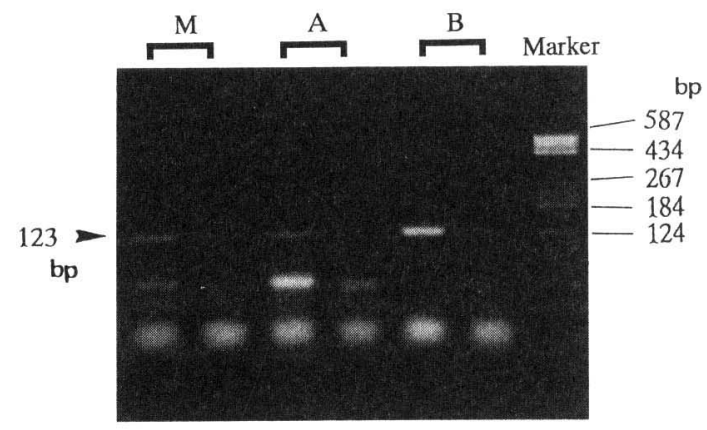

Fig. 1b Case 2

M : Mother ; HPA-4a/a homozygous, A : PCR products from amniotic fluid cells; HPA-4a/a homozygous, B : Infant (infant's blood) ; HPA-4a/a homozygous

臍帯血血小板数は, $38.4 \times 10^{4} / \mu l$, 生後 3 日の血 小板数は, $40.6 \times 10^{4} / \mu l$ であった. 出血傾向はな く，その他異常所見もみとめなかった.

妊娠36週に羊水穿刺を行った．胎児の血小板型 は HPA-4a/a であり，母親と同型であった.また， 出生後児の末梢血を用いたタイピング結果と一致 することを確認した。

\section{症例 3}

母親：29歳, $\mathrm{A}$ 型, RhoD $(+)$, 輸血歴なし. 1 妊 1 産. 妊娠 9 週で抗 HPA- 4 b 抗体陽性と判明

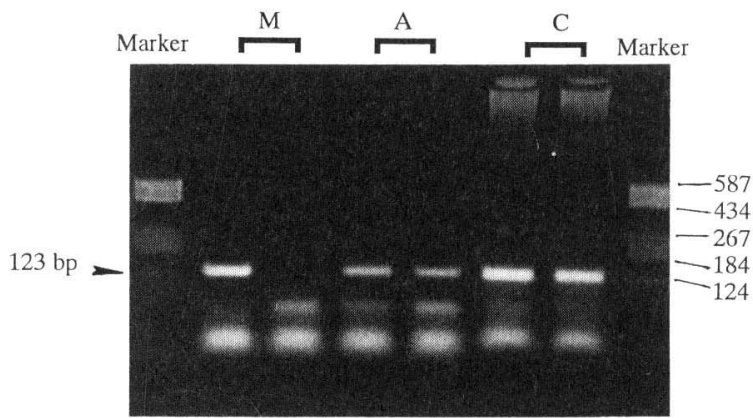

Fig. 1c Case 3

M : Mother ; HPA-4a/a homozygous, A : PCR products from amniotic fluid cells; HPA-4a/b heterozygous, C: Infant (cord blood) ; HPA-4a/b heterozygous

Table 2 Prevalence of Anti-platelet antibodies in 10,880 pregnancies

\begin{tabular}{cc|r|c}
\hline \multicolumn{2}{c|}{ Antibody specificity } & No. (\%) & NAIT \\
\hline \multirow{2}{*}{ Anti-HPA } & $-4 \mathrm{~b}$ & $24(0.22)$ & 3 \\
& $-5 \mathrm{a}$ & $2(0.02)$ & \\
Anti-NAK & $-5 \mathrm{~b}$ & $73(0.67)$ & \\
\hline \multicolumn{2}{c|}{ Total } & 100 & 3 \\
\hline
\end{tabular}

した。妊娠24週時の抗体価は512倍, 分娩直前の抗 体価は256倍であった.妊娠40週で正常分婏にて女 
児を出生した。

児：O 型，RhoD $(+)$

臍帯血血小板数は $11.6 \times 10^{4} / \mu l$ と軽度の血小 板低下を認めたが, 生後 3 日の血小板数は, $28.2 \times$ $10^{4} / \mu l$ に回復した. 出血傾向はなかった.

妊娠 24 週に羊水穿刺し，この羊水細胞を用いて 血小板遺伝子型タイピングを行った．胎児の HPA-4型は HPA-4a/b と同定され, 出生前に母児 間での HPA 型不適合が認められた.

\section{考察}

NAIT は稀な疾患とされてきたが，近年実態が 解明されると共に報告例数も増加している。本邦 では HPA-4b 抗原不適合による NAIT 発症例が 最も多く, 原因抗原として重要である ${ }^{5 / 6)}$. 当部で, 妊婦 10,880 名を対象に，妊娠初期から中期に抗 HPA 抗体スクリーニングを行った結果，抗 HPA-4b 抗体は24名 (0.22\%) に検出された。 又, NAIT を 3 例確診したが, すべて抗 HPA-4b 抗体 によるものだった。NAIT はしばしば第 1 子から 罹患し，重篤な場合，胎児脳内出血，水頭症をお こすといわれている ${ }^{1)}$. 治療法としては，母親への 高単位グロブリン投与, 子宮内血小板輸血などが 考えられる。これら治療を行う場合, 妊娠早期に NAIT 発症の有無を明らかにすることが重要で あり，そのためには妊婦の抗 HPA 抗体スクリー ニングと, 出生前の児の血小板遺伝子型タイピン グが有用である. 血小板遺伝子型は, PCR 法を応 用することによって簡単に判定できるといわれて いる。これまでに報告された血小板型遺伝子夕イ ピングには，増幅した DNA を制限酵素による電 気泳動パターンの大小差によって判定する RFLP 法 (restriction fragment length polymorphism) $)^{7)}$, PCR で増幅した DNA を型特 異的なプローブによって判定する SSO 法 (sequence specific oligonucleotide) ${ }^{8)}$, プライ マーを同種抗原決定塩基に設定し，その増幅の有 無によって判定するSSP 法 (sequence specific primers) ${ }^{344)}$ 等が報告されている．胎児 DNA 情報 を得るサンプルとしては羊水穿刺の他に, 絨毛採 取法, 胎児採血法があり，海外では，これら試料 を使った PCR による各種の胎児血小板型 DNA

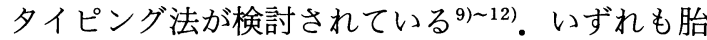
児の血小板型を判定する事が可能で, NAIT の出 生前診断に有用であると報告している。

絨毛採取や胎児血採血は，胎児へのリスクが高 く安全性に問題がある。これと比較し，羊水採取 は容易で危険性が低いと考えられ，羊水細胞は主 として胎児皮膚からの剥脱物，その他胎児の消化 管, 泌尿器, 呼吸器からの脱落上皮など胎児由来 の細胞であり，児の遺伝情報を保有している ${ }^{13)}$ とから試料として用いた.今回の 3 症例において, 羊水細胞の血小板遺伝子型は，臍帯血，末梢血を 用いた児の血小板型と完全に一致し，妊娠早期の 胎児血小板型夕イピング法として，羊水を用いた DNA タイピングが充分に可能であることを示し た.

症例 1 , 症例 2 は, 胎児の血小板遺伝子型が HPA-4a/a であったため, 出生前に NAIT 発症を 否定できた。特に症例 1 では, 高力価の抗 HPA-4 $\mathrm{b}$ 抗体を保有していること, 自然流産を繰り返し ていることから NAIT 発症が危惧されたが, 出生 前の予測どおり NAIT は発症しなかった。 症例 3 は胎児が HPA-4a/b であり, 出生前に母児間血小 板型不適合を認めた為, NAIT 発症を予測し, 充 分な経過観察を行うことができた．羊水細胞を用 いた血小板型 DNA タイピング法は妊娠早期に胎 児の血小板型を正確，迅速に同定でき，抗血小板 抗体陽性妊婦の出生前に NAIT に罹患する可能 性を診断する有用な方法であると考える。

\section{文献}

1) Hermann, J.H., Jumberlic, M.L., Ancona, R.J. and Kickler, T.S.: In utero cerebral hemorrhage in alloimmune thrombocytopenia. Am. J. Pediatr. Hematol. Oncol., 8: 312-317, 1986.

2) Shibata, Y., Juji, T., Nishizawa, Y., Sakamoto, H. and Ozawa, N.: Detection of platelet antibodies by a newly developed mixed agglutination with platelets. Vox Sang., $41: 25-31,1981$.

3）島田和典, 橋口理宏, 高橋智子, 品田章二 : 遺伝 子増幅法を用いた血小板特異抗原型判定法の開 発。日輸血会誌, $39: 486,1993$.

4) Tanaka, S., Taniue, A., Nagao, N., Ohnoki, S., Shibata, H., Okubo, H. and Yamaguchi, H.: Simultaneous DNA typing of human platelet antigen 2,3 and 4 by an allelespecific PCR 
method. Vox Sang., 68: 225—230, 1995.

5）佐治博夫：血小板抗原の分類とその遺伝子解析. 日輸血会誌，40(1)：118-121, 1994.

6）林 律子, 青山憲一, 小松孝良, 鈴木六郎, 高倉 清, 谷上純子, 永尾暢夫, 犬飼和久, 柴田洋一： 3 卵性児に認められた抗 HPA-4b 抗体による新 生児血小板減少症の 1 例. 日輸血会誌, 40(4) : 650 -654, 1994.

7) Newman, P.J., Derbes, R.S. and R.H.: The human platelet alloantigens, $\mathrm{P} 1^{\mathrm{A} 1}$ and $\mathrm{P} 1^{\mathrm{A} 2}$, are associated with a Leucine ${ }^{33}$ Proline $^{33}$ amino acid polymorphism in membrane glycoprotein IIIa, and are distinguishable by DNA typing. J. Clin. Invest., 83 : 1778-1781, 1989.

8) Wang, L., Juji, T., Shibata, Y., Kuwata, S. and Tokunaga, K.: Sequence variation of human platelet membrane glycoprotein IIIa associated with the $\mathrm{Yuk}^{\mathrm{a}} / \mathrm{Yuk}^{\mathrm{b}}$ alloantigen system. Proc. Japn. Acad., 67(ser. B) : 102-106, 1991.

9) McFarland, J.G., Aster, R.H., Bussel, J.B., Gianopoulos, J.G., Derbes, R.S. and Newman, P.J.: Prenatal diagnosis of neonatal alloimmune thrombocytopenia using allele-specific oligonucleotide probes. Blood, 78(9) : 2276 2382, 1991.

10) Bennett, P.R., Warwick, R., Vaughan, J., Chana, H., Kubenko, A. and Fisk, N.: Prenatal determination of human platelet antigen type using DNA amplification following aminocentesis. Br. J. Obstet. Gynecol., 101 : 246 -249, 1994.

11) Madsen, H., Taaning, E., Georgsen, J., Ryder, L.P., Svejgaard, A. and Bock, J.: PCR for fetal platelet HPA-1 alloantigen typing. Lancet, $337:$ 493, 1991.

12) Simsk, S., Christiaens, G.C.L.M., Kanhai, H.H. H., Beekhuis, J.R., Bleeker, P.M.M., Vlekke, A. B.J., Goldschmeding, R. and von dem Borne, A. E.G.Kr.: Human platelet antigen- $1(\mathrm{Zw})$ typing of fetuses by analysis of polymerase chain reaction-amplified genomic DNA from amniocytes. Transfusion Medcine, 4 : 15-19, 1994.

13）望月真人：妊婦の生理標準産科婦人科学, 編者, 望月真人, 桑原慶紀, 医学書院, 東京, 1994, p. 188 -189 . 